\title{
Soil properties and grape yield affected by rock biofertilisers with earthworm compound
}

\author{
N. Pereira-Stamford ${ }^{1 *}$, I. Pereira-Andrade ${ }^{2}$, S. da Silva-Junior ${ }^{1}$, M. Lira-Junior ${ }^{1}$, \\ C. Silva-Santos ${ }^{1}$, A. Santiago de Freitas ${ }^{1}$, P. Van-Straaten ${ }^{3}$ \\ ${ }^{1}$ Department of Agronomy, University Federal Rural of Pernambuco, Dois Irmãos, Recife Pernambuco, \\ Brazil. ${ }^{2}$ Department of Soil Science, University Federal Rural of Amazonas, Paragominas, Amazonas, Brazil. \\ ${ }^{3}$ University of Guelph, School of Environmental Sciences, Guelph, Ontario, Canada. *Corresponding author: \\ newtonps@depa.ufrpe.br
}

\begin{abstract}
Grapes are an important crop in several countries, including Brazil. This study was conducted to evaluate the potential of PK rock biofertilisers on grapes (Vitis vinifera) grown in the San Francisco Valley of the Brazilian semi-arid region. Three sources of PK fertilisers, PK soluble fertilisers, PK rock biofertilisers, and powdered PK rocks, which were all mixed with earthworm compound, and a control treatment consisting only of earthworm compound were tested at three rates. The soil $\mathrm{pH}$, available $\mathrm{P}$ and $\mathrm{K}$, exchangeable $\mathrm{Ca}^{+2}$ and $\mathrm{Mg}^{+2}$, soluble $\mathrm{S}_{-} \mathrm{SO}_{4}^{-2}$, total $\mathrm{Fe}$ and organic carbon were analysed, and the grape yield was evaluated. The soil $\mathrm{pH}$ was affected by the fertilisation treatments and was reduced by the application of PK biofertiliser. The available $\mathrm{P}$ and $\mathrm{K}$, soluble $\mathrm{S}_{-} \mathrm{SO}_{4}^{-2}$, exchangeable $\mathrm{Ca}$ and $\mathrm{Mg}$, total Fe and organic carbon in the soil increased with the application of the PK biofertilisers. The soluble fertiliser had a significant effect $(p=0.01)$ on the recommended rate of the grape yield, but no significant difference was observed between the PK soluble fertiliser and biofertiliser at $150 \%$ of the recommended rate. Rock biofertilisers may be used as a source of $\mathrm{P}, \mathrm{K}, \mathrm{S}_{-} \mathrm{SO}_{4}^{-2}$ and $\mathrm{Fe}$ for grape production in soil with low available $\mathrm{P}$ and $\mathrm{K}$, especially if applied at a $150 \%$ recommended rate.
\end{abstract}

Keywords: Acidithiobacillus; available nutrients; PK fertilisers; PK rocks; rock solubilisation; oxidising bacteria 


\section{Introduction}

Grapes (Vitis vinifera L.) are a major crop in many countries, especially in Europe, the United States, Australia, Chile, Argentina and Brazil. In Brazil, the most important grape fields are found in the uplands of the sub-tropical Rio Grande do Sul state. Recently, grape production has extended into the semi-arid region along the San Francisco River Valley in Northeastern Brazil, where two grape harvests per year are possible with adequate irrigation. Viticulture is always intensively managed, with high agrochemical inputs, including fertilisers (Leão, 2003).

Farmers commonly apply soluble fertilisers to grow grapevines effectively and efficiently. A new concept for long-term growing crops, such as grapes, is using slow-release rock and mineral fertilisers as a means to provide nutrients to soils and crops. Slowrelease rock fertilisers include $\mathrm{P}$ - and K-rich rocks and minerals such as phosphate rocks, biotite and other K-rich volcanic rocks (van Straaten, 2002, 2007).

A way to increase nutrient availability from these products is the use of solubilising microorganisms to produce organic and inorganic acids that attack the rocks (He et al., 1996). Sulphur oxidising bacteria of the Acidithiobacillus genus oxidise elemental sulphur to sulphate, and thus increase the $\mathrm{P}$ availability in the soils (El Tarabily et al., 2006). These bacteria occur naturally in soils, although they are not as abundant in agricultural soils.

There is little information about the effects of elemental sulphur inoculated with oxidative bacteria in the production of $\mathrm{K}$ biofertilisers. Biofertilisers from $\mathrm{P}$ - and K-rich rocks plus elemental sulphur inoculated with Acidithiobacillus have obtained good results for cowpeas, yam beans and first-year sugarcane that are cultivated in acidic soils of the rain forest zone in Northeastern Brazil as reported by Stamford et al. $(2004,2006,2007)$. However, no data are available on their use under semi-arid conditions.

This study compares the effects of PK soluble fertilisers, biofertilisers and powdered rocks, which were applied at different rates, on some soil attributes and on grape yield in the Brazilian San Francisco Valley.

\section{Materials and methods}

\subsection{Biofertiliser production}

The biofertilisers were produced with "Gafsa" natural phosphate, containing $13.6 \%$ total $\mathrm{P}$, and with potassium-bearing rock (biotite) from Santa Luzia, Paraiba, Brazil, containing $9 \%$ total $\mathrm{K}$. The data for $\mathrm{P}$ and $\mathrm{K}$ powdered rocks and $\mathrm{P}$ and $\mathrm{K}$ biofertilisers mixed with organic matter $(\mathrm{OM})$ are presented in Table 1. 
Table 1. Chemical analyses of PK biofertilisers mixed with organic matter (earthworm compound) and powdered $\mathrm{P}$ and $\mathrm{K}$ rocks.

\begin{tabular}{|c|c|c|c|c|}
\hline \multirow{2}{*}{ Chemical analyses } & $\begin{array}{l}\text { P Biofertiliser } \\
\text { plus OM }\end{array}$ & $\begin{array}{c}\text { Natural } \\
\text { phosphate }\end{array}$ & $\begin{array}{l}\text { K Biofertiliser } \\
\text { plus OM }\end{array}$ & Biotite \\
\hline & \multicolumn{4}{|c|}{ } \\
\hline Total $\mathrm{N}$ & 0.91 & 0.00 & 0.92 & 0.00 \\
\hline Total $\mathrm{P}_{2} \mathrm{O}_{5}$ & 31.48 & 29.98 & 0.52 & 0.41 \\
\hline Available P & 5.21 & 0.01 & 0.02 & 0.00 \\
\hline Total $\mathrm{K}_{2} \mathrm{O}$ & 0.82 & 0.10 & 9.81 & 8.06 \\
\hline Available K & 0.12 & 0.00 & 0.99 & 0.98 \\
\hline Total $\mathrm{CaO}$ & 41.76 & 41.09 & 0.22 & 0.27 \\
\hline Total $\mathrm{MgO}$ & 0.40 & 0.32 & 8.53 & 8.28 \\
\hline Total $\mathrm{Fe}_{2} \mathrm{O}_{3}$ & 0.23 & 0.18 & 15.48 & 16.29 \\
\hline Total $\mathrm{MnO}$ & ND & ND & 1.50 & 0.94 \\
\hline Total $\mathrm{Al}_{2} \mathrm{O}_{3}$ & 0.55 & 0.43 & 8.48 & 8.89 \\
\hline $\mathrm{F}$ & 1.37 & 1.23 & 0.43 & 0.31 \\
\hline $\mathrm{pH}-\mathrm{H}_{2} \mathrm{O}(1: 2.5)$ & 6.1 & 6.4 & 6.0 & 6.6 \\
\hline
\end{tabular}

The biofertilisers were prepared separately for $\mathrm{P}$ and $\mathrm{K}$ by mixing each rock with fine powdered elemental sulphur (200 mesh; inoculated with Acidithiobacillus bacteria) using a 10:1 mass-to-mass ratio. The sulphur oxidative bacteria were cultivated in a specific medium (El Tarabily et al., 2006), in $125 \mathrm{~mL}$ Erlenmeyer flasks, at $180 \mathrm{rpm}$ and $24-25^{\circ} \mathrm{C}$, for 5 days. The Acidithiobacillus was applied at $10^{7}$ viable cells $\mathrm{mL}^{-1}$ via an inoculation of a 1:10 (v:v) mixture with distilled water, which was subsequently pulverised into $20-\mathrm{cm}$ deep layers of the rock-sulphur mixture. The mix was kept near field capacity for 60 days, after which the $\mathrm{pH}$ in water and the available $\mathrm{P}$ and $\mathrm{K}$ were determined following the method of Embrapa (1997) with the following results: BP- pH 3.3 and available P $50\left(\mathrm{~g} \mathrm{~kg}^{-1}\right)$ as well as BK- $\mathrm{pH} 3.0$ and available $\mathrm{K} 10\left(\mathrm{~g} \mathrm{~kg}^{-1}\right)$.

The $\mathrm{P}$ and $\mathrm{K}$ biofertilisers were mixed 1:4 (m:m) with earthworm compound (OM) to neutralise excessive acidity to a final $\mathrm{pH}$ of 6.1 and 6.0 , respectively (Table 1).

\subsection{Soil and experimental conditions}

The field experiment was conducted at a production farm (08 $59^{\prime} 49^{\prime}$ ' S, 40 ${ }^{\circ} 16^{\prime} 19^{\prime}$ ' W and altitude of 300 $\mathrm{m})$ of the Botticelli Company, which is located in the San Francisco Valley in Pernambuco state in the semi-arid region of Northeastern Brazil. The climate is classified as BSwh, according to the Köppen classification.

The soil was a medium texture dystrophic Planosol (Embrapa, 1999) that was representative of the region, with low available $\mathrm{P}$ and $\mathrm{K}$, predominantly used to grow grapes and mangoes. The chemical and physical properties of the soil were analysed in soil samples that were collected before the experiment. The soil was analysed using Embrapa (1997) methodology with the following results: $\mathrm{pH}\left(\mathrm{H}_{2} \mathrm{O}\right.$ 1.0:2.5) $=$ 5.8; available $\mathrm{P}=15 \mathrm{mg} \mathrm{dm}^{-3}$; soluble $\mathrm{S}-\mathrm{SO} 4-2=26$ mg dm-3; exchangeable cations $\left(\mathrm{cmolc} \mathrm{dm}^{-3}\right): \mathrm{Ca}^{2+}=$ $1.88, \mathrm{Mg}^{2+}=0.37$ and $\mathrm{K}^{+}=0.18$; micronutrients $(\mathrm{mg}$ 
$\left.\mathrm{dm}^{-3}\right): \mathrm{B}=10.8, \mathrm{Zn}=4.8, \mathrm{Cu}=6.6, \mathrm{Mn}=5.2$ and total $\mathrm{N}=0.7 \mathrm{~g} \mathrm{~kg}^{-1}$ and organic matter $=19.5 \mathrm{~g} \cdot \mathrm{kg}^{-1}$; global density $\left(\mathrm{g} \mathrm{cm}^{-3}\right)=1.67$; bulk density $\left(\mathrm{g} \mathrm{cm}^{-3}\right)$ $=2.63$ and texture $\left(\mathrm{g} \mathrm{kg}^{-1}\right)$ : sand $=650$, silt $=169$ and clay $=181$.

The table grape cultivar "Italia Pirovano" was used due to its high commercial and agricultural value in the region (Leão, 2003). Grape seedlings at 90 days were transplanted into furrows $(40 \times 40 \times 40 \mathrm{~cm})$ in $210 \mathrm{~m}^{2}$ plots $(35.0 \mathrm{~m}$ long and $6.0 \mathrm{~m}$ wide), with two rows that were spaced at $3.5 \times 3.0 \mathrm{~m}$ to yield 20 plants per plot and a total of 1404 plants in the experiment (1.228 ha).

At seedling transplantation, all of the plants received the same basic fertilisation following IPA (2008) recommendations and $2 \mathrm{~L} \mathrm{plant}^{-1}$ of cow manure following the practice of local producers. The fertilisers were applied $20 \mathrm{~cm}$ deep and $20 \mathrm{~cm}$ away from the plant base.

The soil water was maintained near field capacity using computer-controlled micro-irrigation. All grape cultural practices, including pesticide application, were applied weekly after pruning, according to the methods of Embrapa (Brazilian Agricultural Research Company) and as required by the Fruit Integrated Program (FIP) fresh fruit export guidelines. The grapes were pruned to 2 shoots, each with eight to ten gens, two months before each harvest, and the shoots were wrapped onto fruiting wires. The grapes were harvested 110 - 120 days after pruning, and the juice analysis revealed values between 15-18 Brix $^{\circ}$.

\subsection{Experimental design}

The experiment was a factorial arrangement of the fertiliser sources (soluble fertiliser, biofertiliser, powdered rock) and rates [50, 100 and $150 \%$ of the Pernambuco state grape fertilisation recommendation,
IPA (2008)] and was conducted in a randomised block design with four replicates. Fertilisation occurred after each pruning [12 and 22 months after seedling transplantation (AST)], using the same procedure described for basic fertilisation. The fertilisers sources and rates $(\mathrm{P}+\mathrm{K})$ were: (a) soluble $\mathrm{P}$ fertiliser (single superphosphate $=300,450$ and $\left.600 \mathrm{~kg} \mathrm{ha}^{-1}\right)+$ soluble $\mathrm{K}$ fertiliser (potassium sulphate $=70,140$ and $\left.210 \mathrm{~kg} \mathrm{ha}^{-1}\right) ;(\mathrm{b})$ biofertiliser from phosphate rock $(\mathrm{BP}=300,450$ and $\left.600 \mathrm{~kg} \mathrm{ha}^{-1}\right)+$ biofertiliser from potash rock $(\mathrm{BK}=$ 70,140 and $210 \mathrm{~kg} \mathrm{ha}^{-1}$ ); (c) powdered rock phosphate $\left(\mathrm{PR}=1,000,1,500\right.$ and $\left.2,000 \mathrm{~kg} \mathrm{ha}^{-1}\right)+$ biotite bearing rock $\left(B R=1,000,1,500\right.$ and 2,000 $\left.\mathrm{kg} \mathrm{ha}^{-1}\right)$.

A control treatment with earthworm compound $\left(1 \mathrm{~L} \mathrm{plant}^{-1}\right)$ and without $\mathrm{P}$ and $\mathrm{K}$ fertilisation $\left(\mathrm{P}_{0} \mathrm{~K}_{0}\right)$ was used for comparative purposes. The earthworm compound was commercially available in the regional market with $\mathrm{pH}\left(\mathrm{H}_{2} \mathrm{O}\right) 7.9$, total $\mathrm{N} 0.5\left(\mathrm{~g} \mathrm{~kg}^{-1}\right)$, available P $2.0\left(\mathrm{mg} \mathrm{kg}^{-1}\right)$ and available $\mathrm{K} 5.0\left(\mathrm{mg} \mathrm{kg}^{-1}\right)$.

\subsection{Soil analysis and grape yield}

The first harvest (April 2009) produced a low fruit yield while the second harvest in February 2009 (26 months AST) had a normal yield and formed the data presented in this study. The additional treatment without $\mathrm{P}$ and $\mathrm{K}$ fertilisation did not produce fruit due to the insufficient natural soil fertility.

The soil samples were collected at the second grape harvest from 5 plants of the two central rows (10 plants per plot). The soil samples were collected at a depth of $20 \mathrm{~cm}$ in furrows with a distance of 20 $\mathrm{cm}$ from the plant base. Mixed and composite samples were analysed for $\mathrm{pH}$, available $\mathrm{P}$ and $\mathrm{K}$, exchangeable $\mathrm{Ca}^{+2}$ and $\mathrm{Mg}^{+2}$, total $\mathrm{Fe}$ and organic carbon, following the Embrapa (1997) methodology. The soluble $\mathrm{S}^{-\mathrm{SO}_{4}}{ }^{-}$ ${ }^{2}$ was determined using $\mathrm{S}^{-\mathrm{SO}_{4}}{ }^{-2}$-specific kits (Merck) and a spectrophotometer (model TR 420, Merck). 


\subsection{Statistical analysis}

The data was analysed by ANOVA, with significant effects evaluated by Tukey's test $(p=0.01)$ using the SAS Program (SAS Institute, 1999. The regression equation and $\mathrm{R}^{2}$ values between the biofertiliser treatments and the grape yields were calculated, and the soil chemical properties were evaluated.

\section{Results and discussion}

\subsection{Soil properties}

The soil $\mathrm{pH}$, available $\mathrm{P}$ and $\mathrm{K}$ and soluble $\mathrm{S}_{-} \mathrm{SO}_{4}^{-}$ 2 are shown in Table 2 with the regression equations in Table 3. The soil $\mathrm{pH}$ was affected by the different sources of fertilisation, especially the PK rock biofertilisers that were mixed with earthworm compound. However, the reduction in soil $\mathrm{pH}$ was not significant for the fertiliser rate. Other reports also indicate that the low $\mathrm{pH}$ of the PK biofertiliser may influence plant development and include those by Stamford et al. (2005) on applying phosphate rock biofertiliser on seedlings of Mimosa caesalpiniifolia tree legume, Stamford et al. (2006) on sugarcane and Moura et al. (2007) on melon. However, Stamford et al. (2006) used application rates that are higher than those in other studies and have not added organic matter. The authors concluded that the low $\mathrm{pH}(\mathrm{pH}$ 3.0-3.5) of biofertilisers can be neutralised by mixing PK biofertilisers with high $\mathrm{pH}$ organic matter, such as urban waste ( $\mathrm{pH} 8.2$ ) or earthworm compound ( $\mathrm{pH}$ 7.9), and indicated that PK rock biofertilisers applied without organic matter reduces the soil $\mathrm{pH}$, which may be harmful to plants, especially at higher application rates that are usually necessary for yields comparable to those for soluble fertilisers (Stamford et al. 2007, 2009).

Table 2. Soil $\mathrm{pH}$, available $\mathrm{P}$ and $\mathrm{K}$ and soluble $\mathrm{SO}_{4}^{-2}$ that are affected by PK sources (biofertilisers, fertilisers and rocks) and the rates applied in samples that are collected at fruit harvest (26 months after seedling transplantation).

\begin{tabular}{|c|c|c|c|c|}
\hline \multirow{3}{*}{$\begin{array}{l}\text { PK Fertilisation } \\
\text { Sources/rates }\end{array}$} & \multicolumn{4}{|c|}{ Soil analyses } \\
\hline & $\mathrm{pH}$ & Available P & Available K & Soluble $\mathrm{SO}_{4}^{-2}$ \\
\hline & $\mathrm{H}_{2} \mathrm{O}(1.0: 2.5)$ & \multicolumn{3}{|c|}{ 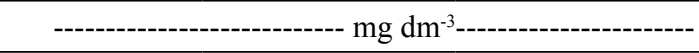 } \\
\hline Fertiliser FPK50 & $6.1 \mathrm{Aa}$ & $18.5 \mathrm{Ca}$ & $81.9 \mathrm{Ba}$ & $15.3 \mathrm{Ab}$ \\
\hline Fertiliser FPK100 & $6.4 \mathrm{Aa}$ & $24.8 \mathrm{Ba}$ & $89.7 \mathrm{Ba}$ & $17.6 \mathrm{Ab}$ \\
\hline Fertiliser FPK150 & $6.7 \mathrm{Aa}$ & $29.4 \mathrm{Aa}$ & $117.0 \mathrm{Aa}$ & $17.2 \mathrm{Ab}$ \\
\hline Biofertiliser BPK50 & $5.5 \mathrm{Ab}$ & $15.2 \mathrm{Ca}$ & $62.4 \mathrm{Bb}$ & $29.3 \mathrm{Ba}$ \\
\hline Biofertiliser BPK100 & $5.6 \mathrm{Ab}$ & $23.5 \mathrm{Ba}$ & $66.3 \mathrm{Bb}$ & $28.5 \mathrm{Ba}$ \\
\hline Biofertiliser BPK150 & $5.7 \mathrm{Ab}$ & $29.9 \mathrm{Aa}$ & 94.1 Aab & $33.1 \mathrm{Aa}$ \\
\hline Rock RPK50 & 6.6 Aa & $4.8 \mathrm{Cb}$ & $54.6 \mathrm{Ac}$ & $9.75 \mathrm{Ac}$ \\
\hline Rock RPK100 & $6.5 \mathrm{Aa}$ & $7.1 \mathrm{Bb}$ & $54.6 \mathrm{Ac}$ & $9.82 \mathrm{Ac}$ \\
\hline Rock RPK150 & $6.7 \mathrm{Aa}$ & $9.0 \mathrm{Ab}$ & $58.5 \mathrm{Ac}$ & $10.00 \mathrm{Ac}$ \\
\hline Control (P0 K0) & 5.0 & $5.1 \mathrm{c}$ & $59.0 \mathrm{c}$ & $9.0 \mathrm{c}$ \\
\hline
\end{tabular}

The values with the same capital letters, indicating comparisons of the rates in the same PK source, and the values with the same small letters, indicating comparisons of the same rate in the different sources were not significantly different by the Tukey's test $(p=0.01)$. 
Table 3. Regression equation and coefficient of determination for soil $\mathrm{pH}$, available $\mathrm{P}$ and $\mathrm{K}$ and soluble sulphur $\left(\mathrm{S}_{-} \mathrm{SO}_{4}^{-2}\right)$, which are affected by the source rates of the fertiliser treatments.

\begin{tabular}{lccc}
\hline Soil parameter & P+K Fertilisers & Regression equation & $\mathrm{R}^{2}$ \\
\hline & & & \\
$\mathrm{pH}$ & Fertiliser FPK & $\mathrm{Y}=5.010+0.0245 \mathrm{x}$ & $0.93^{* *}$ \\
& Biofertiliser BPK & $\mathrm{Y}=4.991+0.0115 \mathrm{x}$ & $0.75^{* *}$ \\
& Rock RPK & $\mathrm{Y}=5.072+0.0326 \mathrm{x}$ & $0.84^{* *}$ \\
& Fertiliser FPK & $\mathrm{Y}=10.185+0.2196 \mathrm{x}$ & $0.94^{* *}$ \\
Available P & Biofertiliser BPK & $\mathrm{Y}=6.299+0.0953 \mathrm{x}$ & $0.95^{* *}$ \\
& Rock RPK & $\mathrm{Y}=5.357-0.0001 \mathrm{x}$ & $0.79^{* *}$ \\
& & & \\
Available K & Fertiliser FPK & $\mathrm{Y}=0.135+0.0011 \mathrm{x}$ & $0.81^{* *}$ \\
& Biofertiliser BPK & $\mathrm{Y}=0.126+0.0008 \mathrm{x}$ & $0.60^{* *}$ \\
& Rock RPK & $\mathrm{Y}=0.106+0.0002 \mathrm{x}$ & $0.45^{*}$ \\
Soluble S-SO4-2 & Fertiliser FPK & $\mathrm{Y}=7.966+0.1790 \mathrm{x}$ & $0.79^{* *}$ \\
& Biofertiliser BPK & $\mathrm{Y}=9.938+0.2400 \mathrm{x}$ & $0.78^{* *}$ \\
\hline
\end{tabular}

In the equation, ' $\mathrm{X}$ ' corresponds to the fertiliser that was applied at the recommended rate and ' $\mathrm{Y}$ ' corresponds to the soil property that was analysed. NS= not significant.

Soluble fertilisers and PK biofertilisers presented higher amounts of available $\mathrm{P}$ and $\mathrm{K}$ than powdered rocks or the control treatment without $\mathrm{P}$ and $\mathrm{K}$ fertilisation (Table 2). These results are similar to those of Stamford et al. (2006) showing the effects of PK rock biofertilisers that were applied to sugarcane cultivated in coastal tableland soils with low available $\mathrm{P}$ and $\mathrm{K}$, especially at higher application rates.

The effects of fertilisation (sources and rates) on $\mathrm{S}_{-} \mathrm{SO}_{4}^{-2}$ were observed when a PK biofertiliser was applied (Table 3), especially at a higher application rate (150\% recommended rate), probably due to the sulphuric acid produced by the Acidithiobacillus. This finding explains the increase in available nutrients that are contained in the $\mathrm{P}$ and $\mathrm{K}$ rocks after the production of the $\mathrm{PK}$ rock biofertilisers compared to the original rocks that were used to produce the biofertiliser (Table 1).

The exchangeable $\mathrm{Ca}$ and $\mathrm{Mg}$, total $\mathrm{Fe}$ and organic carbon are shown in Table 4 with the regression analyses in Table 5. Both PK biofertiliser and PK rock increased the exchangeable $\mathrm{Ca}$ and $\mathrm{Mg}$ in the soil by approximately $100 \%$ when compared to either soluble fertiliser or the control treatment. Similar results were observed by Stamford et al. (2006), who evaluated PK rock biofertilisers on growth of sugarcane in a coastal table and soil, and Moura et al. (2007), who assessed melons that were cultivated in the semi-arid soil of the San Francisco region. 
Table 4. Exchangeable $\mathrm{Ca}^{+2}$ and $\mathrm{Mg}^{+2}$, total $\mathrm{Fe}^{+2}$ and organic carbon in soil are affected by PK sources (biofertilisers, fertilisers and rocks) that are applied at different rates.

\begin{tabular}{|c|c|c|c|c|}
\hline \multirow{3}{*}{$\begin{array}{c}\text { PK } \\
\text { Fertilisation } \\
\text { Sources/rates }\end{array}$} & \multicolumn{4}{|c|}{ Soil Analyses } \\
\hline & $\begin{array}{l}\text { Exchangeable } \\
\qquad \mathrm{Ca}^{+2}\end{array}$ & $\begin{array}{c}\text { Exchangeable } \\
\mathrm{Mg}^{+2}\end{array}$ & $\begin{array}{l}\text { Total } \\
\mathrm{Fe}^{+3}\end{array}$ & $\begin{array}{l}\text { Organic } \\
\text { C }\end{array}$ \\
\hline & $\mathrm{cmol}_{\mathrm{c}} \mathrm{dm}^{-3}$ & $\mathrm{cmol}_{\mathrm{c}} \mathrm{dm}^{-3}$ & $\mathrm{~g} \mathrm{dm}^{-3}$ & $\mathrm{~g} \mathrm{dm}^{-3}$ \\
\hline Fertiliser FPK50 & $0.43 \mathrm{Ab}$ & $0.20 \mathrm{Ab}$ & $56.4 \mathrm{Bb}$ & $4.31 \mathrm{Ab}$ \\
\hline Fertiliser FPK100 & $0.44 \mathrm{Ab}$ & $0.23 \mathrm{Ab}$ & $63.2 \mathrm{Ab}$ & $4.72 \mathrm{Ab}$ \\
\hline Fertiliser FPK 150 & $0.58 \mathrm{Ab}$ & $0.25 \mathrm{Ab}$ & $72.3 \mathrm{Ab}$ & $4.76 \mathrm{Ab}$ \\
\hline Biofertiliser BPK50 & $0.77 \mathrm{Aa}$ & $0.33 \mathrm{Ba}$ & $95.1 \mathrm{Ba}$ & $7.26 \mathrm{Ba}$ \\
\hline Biofertiliser BPK100 & $0.78 \mathrm{Aa}$ & $0.37 \mathrm{Ba}$ & $113.7 \mathrm{Aa}$ & $9.68 \mathrm{Aa}$ \\
\hline Biofertiliser BPK150 & $0.79 \mathrm{Aa}$ & $0.49 \mathrm{Aa}$ & $120.8 \mathrm{Aa}$ & $11.89 \mathrm{Aa}$ \\
\hline Rock RPK50 & $0.70 \mathrm{Aa}$ & $0.20 \mathrm{Ab}$ & $82.4 \mathrm{Ba}$ & $5.64 \mathrm{Ab}$ \\
\hline Rock RPK100 & $0.74 \mathrm{Aa}$ & $0.20 \mathrm{Ab}$ & $113.9 \mathrm{Aa}$ & $5.79 \mathrm{Ab}$ \\
\hline Rock RPK150 & $0.75 \mathrm{Aa}$ & $0.24 \mathrm{Ab}$ & $121.8 \mathrm{Aa}$ & $5.47 \mathrm{Ab}$ \\
\hline Control (P0 K0) & $0.44 \mathrm{~b}$ & $0.19 \mathrm{~b}$ & $53.9 \mathrm{~b}$ & $4.94 \mathrm{~b}$ \\
\hline
\end{tabular}

The values with the same capital letters, indicating are not significantly different comparisons of the rates in the same PK source and the values with the same small letters, indicating comparisons of the same rate in the different sources, were not significantly different by the Tukey's test $(p=0.01)$. 
Table 5. The regression equation and coefficient of determination for exchangeable $\mathrm{Ca}^{+2}$ and $\mathrm{Mg}^{+2}$, total $\mathrm{Fe}$ and organic carbon in soil are affected by sources of fertiliser treatments that are applied at the recommended rate.

\begin{tabular}{lccc}
\hline \multicolumn{1}{c}{ Analysed variable } & Fertilisation & Regression Equation & $\mathrm{R}^{2}$ \\
\hline Exchangeable $\mathrm{Ca}^{+2}$ & Fertiliser FPK & $\mathrm{Y}=0.370+0.0009 \mathrm{x}$ & $0.69^{* *}$ \\
& Biofertiliser BPK & $\mathrm{Y}=0.365+0.0065 \mathrm{x}$ & $0.88^{* *}$ \\
& Rock RPK & $\mathrm{Y}=0.367+0.0074 \mathrm{x}$ & $0.81^{* *}$ \\
Exchangeable $\mathrm{Mg}^{+2}$ & Fertiliser FPK & $\mathrm{Y}=0.132+0.0017 \mathrm{x}$ & $0.79^{* *}$ \\
& Biofertiliser BPK & $\mathrm{Y}=0.142+0.0036 \mathrm{x}$ & $0.86^{* *}$ \\
& Rock RPK & $\mathrm{Y}=0.143+0.0007 \mathrm{x}$ & $\mathrm{NS}$ \\
Total Fe & Fertiliser FPK & $\mathrm{Y}=55.982+0.0719 \mathrm{x}$ & $\mathrm{NS}$ \\
& Biofertiliser BPK & $\mathrm{Y}=57.552+0.6827 \mathrm{x}$ & $0.65^{*}$ \\
Rock RPK & $\mathrm{Y}=28.218+0.0059 \mathrm{x}$ & $\mathrm{NS}$ \\
Organic carbon & Fertiliser FPK & $\mathrm{Y}=4.215+0.0089 \mathrm{x}$ & $\mathrm{NS}$ \\
& Biofertiliser BPK & $\mathrm{Y}=5.078+0.0612 \mathrm{x}$ & $0.88^{* *}$ \\
& Rock RPK & $\mathrm{Y}=4.949+0.0188 \mathrm{x}$ & $0.55^{*}$ \\
\hline
\end{tabular}

(1) In the equation ' $\mathrm{X}$ ' correspond to the fertilier that was applied at the recommended rate and ' $Y$ ' corresponds the analyed variable.

The effect of $\mathrm{Ca}$ and $\mathrm{Mg}$ release from apatite and biotite rocks was demonstrated by Novais and Smith (1999) and Nascimento (2003), who applied very high rates of powdered rocks. In this case, the effect may be promoted by the native oxidative bacteria from the soil that influenced the liberation of elements contained in the rocks during the period of plant growth. According to Nahas (2007), soluble mineral fertilisers significantly increased bacterial activity and produced alkaline phosphatase as a result of adding natural powdered phosphate. Similar effects on the soil nutrient availability were also observed by El Tarabily et al. (2006) in soil treated with elemental sulphur inoculated with oxidative bacteria.

The effect of the application rate on the total $\mathrm{Fe}$ was more than ten times higher when PK biofertiliser was used than for either of the remaining PK sourc- es (Table 5), and the effects on organic carbon were similar though not as strong. The effect of minerals to increase the release of potassium was described by Bortoluzzi et al. (2005) and may be produced by a reaction with goethite and hematite that often occurs in humid tropical regions, especially in soil submitted to high moisture and elevated temperature.

\subsection{Grape yield}

There was a significant source $\mathrm{x}$ rate interaction for grape yields (Table 6), indicating that at the recommended rate or lower, a significant yield increase was found for soluble fertiliser over biofertiliser. However, this increase did not occur at $150 \%$ of the recommended rate. Both soluble and biofertiliser PK sources produced significantly higher yields than 
powdered rock. It is important to notice that biofertiliser at $150 \%$ of the recommended rate achieved simi- lar yields to the soluble fertiliser at the recommended rate, which may have economic importance.

Table 6. Grape yield (harvested 26 months after seedling transplantation) is affected by PK sources (fertilisers, biofertilisers and rocks) that are applied at three rates in soil from the San Francisco Valley, a semi-arid region of Brazil.

\begin{tabular}{lccc}
\hline \multirow{2}{*}{ Fertiliser } & \multicolumn{3}{c}{ Fertilisers (recommended rate - \%) } \\
\cline { 2 - 4 } & 50 & Grape yield $\left(\mathrm{t} \mathrm{ha}^{-1}\right)$ & 150 \\
\cline { 2 - 4 } & $14.6 \mathrm{Ca}$ & $17.7 \mathrm{Ba}$ & $21.6 \mathrm{Aa}$ \\
\hline Fertiliser FPK & $7.9 \mathrm{Cb}$ & $11.8 \mathrm{Bb}$ & $18.9 \mathrm{Aa}$ \\
Biofertiliser BPK & $1.7 \mathrm{Bc}$ & $2.4 \mathrm{Bc}$ & $4.8 \mathrm{Ab}$ \\
Rock RPK & & & \\
\hline
\end{tabular}

The values with the same capital letters, indicating comparisons of the rates in the same PK source, and the values with the same small letters, indicating comparisons of the same rate in the different sources, were not significantly different by the Tukey's test $(p=0.01)$. Stamford et al. $(2005,2006)$ and Moura et al. (2007) conducted field experiments comparing soluble fertilisers and biofertilisers on the growth of cowpea, sugarcane and melons, respectively, and observed a greater response to biofertiliser application in a shorter time frame, even for the perennial sugarcane, when compared to grapes.

Stamford et al. (2004) had described the effect of applying $\mathrm{P}$ biofertiliser, compared to soluble phosphate or a rock phosphate and sulphur mix that was not inoculated with Acidithiobacillus, on mimosa grown in an acid soil and found a gain for the biofertiliser. However, Klepker and Anghinoni (1995) found higher corn yields for soluble fertiliser than for acidulate rock apatite from a different origin. These results indicate the continued need for localised research on alternate fertilisers.

\section{Conclusions}

This study demonstrates for the first time that biofertilisers that are produced with phosphate and potash rocks plus elemental sulphur inoculated with Acidithiobacillus may be used as a source of $\mathrm{P}, \mathrm{K}, \mathrm{S}_{-} \mathrm{SO}_{4}^{-2}$ and $\mathrm{Fe}$ to improve grape yields in soils with low availability of $\mathrm{P}$ and $\mathrm{K}$.

\section{Acknowledgements}

the authors thank the Conselho Nacional de Desenvolvimento Científico e Tecnológico - CNPq, Fundação de Apoio à Ciência e Tecnologia do Estado de Pernambuco - FACEPE and Banco do Nordeste do Brazil - BNB, for financial support and scholarships. The authors also thank the Botticelli industry for fine wine in the San Francisco Valley, Pernambuco, Brazil and for the cession of the grape field, work facilities and specific analyses. 


\section{References}

Bortoluzzi, E.C., Santos, D.R., Kaminski, J., Gatiboni, C., Tessier, D. 2005. Alterações na mineralogia de um Argissolo do Rio Grande do Sul submetido à fertilização potássica. Braz. J. Soil Sci. 29, 327335.

El Tarabily, K.A., Soaud, A.A., Saleh, M.E., Matsumoto, S. 2006. Isolation and characterization of sulfur-bacteria, including strains of Rhizobium from calcareous soils and their effects on nutrient uptake and growth of maize (Zea mays L.). Aust. J. Agric. Res. 57, 101-111.

Embrapa - Empresa Brasileira de Pesquisa Agropecuária. 1999. Sistema Brasileiro de Classificação dos Solos, Rio de Janeiro.

Embrapa, Empresa Brasileira de Pesquisa Agropecuária. 1997. Manual de Métodos de Análise de solo, Rio de Janeiro.

He, Z.L., Baligar, V.C., Martens, D.C., Ritchey, K.D., Kemper, W.D. 1996. Factors affecting phosphate rock dissolution in acid soil amended with liming materials and cellulose. Soil Sci. Soc. Am. J. 60, 1596-1601.

IPA, Instituto de Pesquisas Agronômicas de Pernambuco. 2008. Recomendações de adubação para o estado de Pernambuco. Recife.

Klepker, D., Anguinoni, I. 1995. Crescimento radicular e aéreo do milho em vasos, em função do nível de fósforo no solo e da localização do adubo fosfatado. Braz. J. Soil Sci. 19, 403-408.

Leão, P.C.S. 2003. Uva de mesa produção - Aspectos técnicos. Embrapa semi-árido. Petrolina, 128p.

Moura, P.M., Stamford, N.P., Duenhas, L.H., Santos, C.E.R.S., Nunes, G.H.S., 2007. Eficiência de biofertilizantes de rochas com Acidithiobacillus em melão. Braz. J. Agric. Sci. 2, 1-7.
Nahas, E. 2007. Phosphate solubilizing microorganisms: Effect of carbon, nitrogen, and phosphorus sources. In: Velázquez, E.; Rodríguez-Barrueco, C. Springer Publishers, Salamanca, Spain, 102, 111-115.

Nascimento, M. 2003. A importância e função dos fertilizantes em uma agricultura sustentável e competitiva. CETEM/MCT, Rio de Janeiro, 75p.

Novais, R.F., Smith, T.J. 1999. Fósforo em solo e planta em condições tropicais. Universidade Federal de Lavras, Viçosa, Brazil, 399p.

Stamford N.P., Moura P.M., Lira Junior, Santos, C.E.R.S., Duenhas, L.H., Gava, A.T. 2009. Chemical attributes of an Argisoil of the Vale do São Francisco after melon growth with phosphate and potash rocks biofertilizers. Braz. J. Hortic. 27, 442- 447.

Stamford, N.P., Santos, C.E.R.S., Dias, S.H.L. 2007. Phosphate rock biofertilizer with Acidithiobacillus and rhizobia improves nodulation and yield of cowpea (Vigna unguiculata) in greenhouse and field conditions. Trop. Grassl. 41, 222-230.

Stamford, N.P., Lima, R.A., Santos, C.E.R.S., Dias, S.H.L. 2006. Rock biofertilizers with Acidithiobacillus on sugarcane yield and nutrient uptake in a Brazilian soil. Geomicrobiol. J. 23, 261-265.

Stamford, N.P., Santos, C.E.R.S., Santos, P.R., Santos, K.S., Montenegro, A. 2005. Effects of rock phosphate, sulphur with and without Acidithiobacillus and organic-by products on mimosa (Mimosa caesalpiniifolia) grown in a Brazilian tableland soil. Trop. Grassl. 39, 54-61.

Stamford, N.P., Moura, A.M.M.F., Santos, K.S., Santos, P.R., 2004. Atuação de Acidithiobacillus na solubilização de fosfato natural em solo de tabuleiro cultivado com jacatupé (Pachyrhizus erosus). Braz. J. Soil Sci. 28, 75-83. 
Stamford, N.P., Freitas, A.D.S., Ferraz, A.M., Santos, C.E.R.S. 2003. Nitrogen fixation and growth of cowpea (Vigna unguiculata) and yam bean (Pachyrhizus erosus) in a sodic soil affected by gypsum and sulphur inoculated with Thiobacillus and rhizobial inoculation. Trop. Grassl. 38, 11-17.
Van Straaten, P. 2002. Rocks for crops: agrominerals of Sub-Saharan Africa. Nairobi, Icraf, 388p.

Van Straaten, P. 2007. Agrogeology - The use of rocks for crops. Enviroquest, Cambridge, Ontario, Canada, 440p. 
